\title{
Correlation between IL-10 Expression with Histopathology Type on Nasopharyngeal Carcinoma Patients
}

\author{
Hamita $^{1}$, Widodo Ario Kentjono ${ }^{1}$, H.M.S. wiyadi $^{1}$ \\ ${ }^{1}$ Department of Otolaryngology and Neurology, Faculty of Medicine, Universitas Airlangga, \\ Dr. Soetomo Teaching Hospital, Surabaya 60285, Indonesia
}

\begin{abstract}
Background: Nasopharyngeal carcinoma (NPC) is a malignancy derived from lymphoepithelial tissue and nasopharyngeal epithelial cells. The response therapy of NPC evaluated from histopathological type, but in some patients with the same type was illustrated a different response of therapy. IL-10 expression expects to predict a better response therapy of NPC. IL-10 expression by immunohistochemical examination associated with the differentiation of tumors.

Method: The study was analytic observational with the cross-sectional approach. Samples were collected by consecutive sampling and formalin-fixed, paraffin-embedded biopsy specimens were obtained.

Result: The result of IL-10 expression in Nasopharyngeal carcinoma (NPC) patients with histopathological World health organization (WHO) type I was obtained; From all the samples, there were $36.36 \%$ of strong positive expression and $63.64 \%$ of frail positive expression. There were increases in the number of cells that give a strong expression on WHO type III. Statistical analysis using Fisher's exact test was obtained $\mathrm{p}=$ 0.040 with a contingency coefficient of 0.384 .
\end{abstract}

Conclusion: There was a moderate correlation between IL-10 expression and histopathological type in NPC patients.

Keyword: Nasopharyngeal Carcinoma, Expression IL-10, Histopathological Type.

\section{Introduction}

Nasopharyngeal carcinoma (NPC) is a malignancy derived from lymphoepithelial and nasopharyngeal epithelial tissue. The response to NPC therapy has been assessed by histopathopathology, but in reality, NPC patients with the same histopathologic type might showing a different therapeutic response. ${ }^{1}$ This proves that histopathologic types not accurate enough to predict the treatment response of NPC. IL-10 could be associated

\section{Corresponding Author:}

\section{Widodo Ario Kentjono}

Department of Otolaryngology and Neurology, Faculty of Medicine, Universitas Airlangga, Dr. Soetomo Teaching Hospital, Surabaya-60285, Indonesia e-mail: widodo.arioken@gmail.com with NPC histopathology type and serve as a marker for predicting therapeutic response.

The expression IL-10 levels are increased significantly in the World health organization (WHO) Type III compared to WHO type $\mathrm{I}^{2}$. The statement was supported by other research at Dr. Moewardi Surakarta which showed that IL-10 expression increased in WHO type $\mathrm{III}^{3}$. Examination of IL-10 expression and histopathologic type is expected to provide the best prediction of therapeutic response in NPC patients. Until now, the relationship between IL-10 expression and histopathology type in NPC patients that came to treat in Outpatient Oncology Unit (URJ) of Otolaryngology Dr. Soetomo Teaching Hospital Surabaya is not known yet.

Histopathologies NPC WHO type II and III are known to have a better therapeutic response, but not all of it provide the complete therapeutic response. ${ }^{4}$ 
According to Bergonie and Tribondeau's laws, the sensitivity of cells to radiation is inversely proportional to the degree of differentiation that the worse the cell differentiation rate the better the therapeutic response ${ }^{5}$. WHO Type II nasopharyngeal carcinoma has a degree of moderate-differentiation, and WHO type III has no differentiation. ${ }^{6}$ Another research obtained the same therapeutic response results in the three types of histopathology NPC especially in stage III and IV.

IL-10 is produced by Epstein-Barr Virus-encoded RNAs (EBER) in-situ at the nucleus of NPC cells ${ }^{2}$ EBER-containing tissues was exhibited radio sensitive properties and thus have a better prognosis for radiotherapy ${ }^{7}$. Several studies have reported the role of IL-10 in the development of NPC ${ }^{7,8}$ The data above that showed IL-10 levels were found in stem-cell squamous cell carcinoma (SCC) $)^{9}$. Another research found a significant correlation between Epstein-Barr Virus (EBV) Load and IL-10, that used to assess the response of NPC therapy. Besides, showed that IL-10 expression might be a factor for assessing the therapeutic response and prognosis of NPC sufferers and associated with SCC oral cell transformation seen from its histopathologic type $^{7}$ The role of IL-10 in the development of NPC cells in several ways is to increase cell differentiation, suppress local immune responses, stimulate proliferation, induce angiogenesis, and inhibit apoptosis ${ }^{10}$

The Epstein Barr virus codes for EBV-encoded RNAs (EBER) is responsible for the production of IL-10 or BCRF1 in the nucleus of NPC cells. The IL10 protein has a homologous amino acid with IL-10 produced by the body and acts as an autocrine growth factor for NPC cells. IL-10 stimulates the activation of Signal transducer and activator of transcription 3 (STAT3) which affected cell differentiation and cause invasive growth of the nasopharyngeal epithelial cell layer, that it eventually becomes a carcinoma cell ${ }^{10,11}$ Therefore, we aimed to know the correlation between IL-10 expression and histopathological type in NPC patients. Aim this research to know the correlation between IL-10 expression and histopathological type in NPC patients.

\section{Method}

The research was conducted in Outpatient Oncology Unit (URJ) of Otolaryngology and Installation of Anatomical pathology (AP) Dr. Soetomo Teaching Hospital Surabaya also at PA Installation of Dr. Sardjito Yogyakarta. The research design was used analytic observational research with the cross-sectional approach. The sample used in the study was NPC patients with biopsy results; WHO type I, II and III in the outpatient of oncology unit Dr. Soetomo Teaching Hospital, Surabaya from October to December 2016 and has never received radio chemotherapy and agree to be included as a sample of research (informed consent).

The paraffin block from the biopsy result was cut and immunohisto chemistry on rabbit polyclonal antibody and Anti-IL-10 ab34843 (Abcam ${ }^{\circledR}$, Cambridge - UK). The intracellular expression of IL-10 in the NPC network was identified by the presence of a diffuse, brownish granule image in the cytoplasm of cancer cells against a background of lymphocytes. Assessment of IL-10 expression was performed based on the Allred scale. The intracellular IL-10 expression was observed in 5 fields of view with a 400x enlarged binocular microscope. The data obtained using Fisher's Exact and Contingency Coefficient with $\alpha=0,05$.

\section{Results}

Table 1: The demographic Characteristics of NPC patients $(n=33)$

\begin{tabular}{|c|c|c|}
\hline Characteristics & Amount & Percentage (\%) \\
\hline \multicolumn{3}{|l|}{ Age (y/o) } \\
\hline $20-29$ & 3 & 9.10 \\
\hline $30-39$ & 2 & 6.06 \\
\hline $40-49$ & 11 & 33.33 \\
\hline $50-59$ & 12 & 36.36 \\
\hline $60-69$ & 5 & 15.15 \\
\hline \multicolumn{3}{|l|}{ Sex } \\
\hline Male & 24 & 72.73 \\
\hline Female & 9 & 27.27 \\
\hline \multicolumn{3}{|l|}{ Ethics } \\
\hline Javanese & 25 & 75.76 \\
\hline Madura & 7 & 21.21 \\
\hline Minahasa & 1 & 3.03 \\
\hline \multicolumn{3}{|l|}{ Jobs } \\
\hline Farmer & 10 & 30.30 \\
\hline Driver & 4 & 12.13 \\
\hline Factory Employees & 2 & 6.06 \\
\hline Civil Servant & 1 & 3.03 \\
\hline Merchant & 7 & 21.21 \\
\hline Mechanic & 2 & 6.06 \\
\hline Construction Worker & 2 & 6.06 \\
\hline Teacher & 2 & 6.06 \\
\hline Unemployed Housewife & 2 & 6.06 \\
\hline Police & 1 & 3.03 \\
\hline
\end{tabular}


The distribution data of NPC WHO patients type 1, 2 and 3 based on age, sex, ethnicity, and occupation are shown in Table 1 with the total samples obtained were 33 patients. The age distribution of the most NPC sufferers was 50 to 59 years old (36.36\%), whereas the age distribution of NPC sufferers was lowest in the age group 30 to 39 years $(6.06 \%)$. The youngest age of NPC was 20 years old while the oldest was 67 years old. Patients with NPC was male $(72.73 \%)$ more than female $(27.27 \%)$. The highest number of NPC sufferers in Javanese $(75.76 \%)$ and most of them were farmers $(30.30 \%)$.

Table 2: The results of the IL-10 expression examination on NPC histopathology type based on WHO

\begin{tabular}{|c|c|c|c|c|c|c|}
\hline \multirow{2}{*}{ IL-10 Expression } & \multicolumn{4}{|c|}{ The types of histopatologiNPC } & \multirow[b]{2}{*}{$\mathbf{p}$} & \multirow{2}{*}{$\mathbf{C}$} \\
\hline & I & II & III & Total & & \\
\hline Weak & $2(9.5 \%)$ & $12(57.1 \%)$ & $7(33.3 \%)$ & $21(63.64 \%)$ & \multirow{3}{*}{0.040} & \multirow{3}{*}{0.384} \\
\hline Strong & $1(8.3 \%)$ & $2(16.7 \%)$ & $9(75.0 \%)$ & $12(36.36 \%)$ & & \\
\hline Total & $3(9.1 \%)$ & $14(42.4 \%)$ & $16(48.5 \%)$ & $33(100 \%)$ & & \\
\hline
\end{tabular}

The result analysis of the correlation between IL10 expression with histopathology type of NPC patient based on WHO is shown in Table 2. The most common type of NPC histopathology was WHO type III; 16 patients and 9 have strong of IL-10 expressing. At least known of NPC histopathology type was WHO type I; 3 patients, where 2 of them have frail of IL-10 expressing. Strong intracellular IL-10 expression was $36.36 \%$ of all patients, whereas intracellular IL-10 expression was frail at $63.64 \%$ of all patients.

\section{Discussion}

Based on the result, the age distribution of NPC sufferers were mostly in the age group 50-59 years old, followed by $40-49$ years old, and $60-69$ years old. NPC cells might originate from normal cells undergoing malignant transformation due to spontaneous mutations or carcinogen induction. Transformation of normal cells into cancer required a long induction of time for 15 to 30 years. Nasopharyngeal carcinoma was rare in children about $1-5 \%$ of all cancers ${ }^{12}$ NPC predisposing factors in productive age were the result of exposure to carcinogenic substances or pollution, latent EBV infection and decreased immune factors. It has led to a high incidence of NPC at the age of 40-60 years old ${ }^{13}$

Previous studies, from 40 patients NPC in Dr. Soetomo Teaching Hospital Surabaya reported that the highest incidence of NPC in the age group 50-59 years (35.71\%), followed by age group $40-49$ years (33.33\%), and age group 60-69 years (14.29\%). Research in Semarang, from 128 NPC sufferers, the age group was
40-49 years old (32.80\%) followed by age group 50-59 years old (31.30\%) and age group 30-39 years (10.90\%). Other studies also showed similar results, the ratio of male and female NPC patients was 2.5: 1, and in other centers is $2: 1^{14}$. The high incidence of NPC in males versus females was due to differences in living habits and occupations that tend to be more frequent in contact with carcinogenic causes. Living habits such as smoking, exposure to steam, dust fumes and chemical gases in the workplace increase the risk of NPC 2-6 times ${ }^{15}$.

The distribution of NPC patients based on ethnicity in the study was Javanese $(75.76 \%)$, followed by Madurese (21.21\%) and Minahasa (3.03\%). Many NPC sufferers were from Javanese because the research was conducted in Surabaya which majority of the population was Javanese. Previous research on genetics has found that the human leukocyte antigen (HLA) gene allele has the potential to cause susceptibility to NPC. The incidence of NPC in Indonesia was intermediate levels caused by a combination of environmental factors and EBV infection. Previous research showed almost the same result that most ethnic from 42 patients of NPC in Dr. Soetomo Teaching Hospital Surabaya was a Javanese ethnic group of $66.67 \%$, followed by Madurese, Flores, and Balinese.

The most types of job in patients with NPC in Dr. Soetomo Teaching Hospital Surabaya was a farmer $(30.30 \%)$, and trader $(21.21 \%)$. It was because farmers were exposed to pesticides chronically, and exposure to workers in the form of dust or particles of medium size (5-10 $\square \mathrm{m}$ ) where the particles were easily absorbed 
by the nasopharyngeal mucosa .Cigarette smoke and exposure to formaldehyde and wood dust were also a risk factor for NPC.There were several major chemicals were known to cause NPC based on occupational exposure, including bleach, acid and base agents, sulfuric acid, inks, formaldehyde, and pesticides. The result was similar to the previous research, it was reported the most job was farmers 16 patients (38.09\%) and self-employed 6 patients $(14.29 \%)^{17}$ Several epidemiological studies have shown increased risk factors for NPC in workers exposed to wood dust in certain periods and doses.

The most common type of histopathology in the study was WHO type III, followed by type II, and type I. Previous studies reported the most common type of NPC histopathology found in Indonesia was WHO type III ${ }^{8}$ Other studies that showed similar results of NPC WHO type III was ranked first and followed WHO type II and type $\mathrm{I}^{2}$.WHO type III of nasopharyngeal carcinoma was common because the main cause of NPC in endemic areas was caused by exposure to EBV infection.

Based on the analysis of the results of the study showed a significant correlation $(p=0.04)$ between the expression of IL-10 with histopathology type NPC WHO type I, II, and III with contingency coefficient (C) $=0.384$, which means there was a moderate positive correlation between the two variables. The results were supported by the existing theory that IL-10 plays a role in increasing the differentiation of NPC cells WHO types I, II, and III through STAT3 activation. Increased activation of STAT3 in epithelial cells infected with EBV involves Janus kinase-1 (JAK1), Activating protein-1 (AP1), Jun $\mathrm{N}$ kinase (JNK), and Tyrosine kinase-2 (TYK2). The IL-10 bond with receptors was related to the activation of Jak tyrosine kinases and stimulates downstream signaling. Activation of JAK1, TYK2, and STAT3 was involved in signaling cascades. STAT3 activation plays a role in tumor formation and progression by triggering the invasive growth of independent nasopharyngeal epithelial cell layer into carcinoma cells ${ }^{8}$

Histologic studies showed a different type of histopathology NPC was a homogeneous variation in the neoplasm group. Histogenetically, all NPC types were derived from squamous cells and to distinguish between NPC WHO type II and type III were used electron microscopy and immunohistochemical examination $^{20}$ Tumor differentiation has been known to occur in sarcomas ${ }^{21}$ The phenomenon was also recognizable in NPC and was common in recurrent lesions, tumors undergoing metastasis to lymph nodes and exhibiting different types of histopathology than at the start of the diagnosis. The results of the study were similar to demonstrated that expression and IL-10 levels significantly increased in NPC WHO type III compared to WHO type II also reported that activation of LMP-1 in NPC helped stimulate the production of IL-10 with the help of CD4.

The results of the study were also according to research in Dr.Moewardi General Hospital Surakarta which showed that IL-10 expression increased in NPC of WHO type III. Stromal inflammatory and cytokinins systems play a role in stimulating growth and expression of latent and lytic EBV genes in NPC epithelial cells. A cytokine that removed from inflammatory cells will cause the activation of NF- $\square$ B and STAT3 signal systems in epithelial cells infected with EBV. Chronic inflammation of epithelial cells infected with EBV plays a role in the pathogenesis of NPC WHO type III ${ }^{19}$ The study on 325 samples of oral SCC patients with immunohistochemical staining was found an increase in IL-10 expression that correlates with aggressive clinical symptoms and it could be a predictor of therapeutic respons. It was performed an immunohistochemical staining on oral SCC to prove an association of IL-10 expression with progressive oral of SCC cell transformation, which was examined from histopathologic types. Similarly with another result that found IL-10 expression was significantly associated with treatment response and poor prognosis in gastric cancer.

Recently, a therapeutic response based on histopathologic type. however, in reality, NPC patients with the same histopathologic type might be exhibit different therapeutic responses that requiring additional examination to predict a more accurate treatment response. The study has demonstrated the association of IL-10 expression with histopathologic type (NPC WHO types I, II, and III) which indispensable to predict a more accurate treatment response in NPC patients.

\section{Conclusion}

There was a moderate correlation between IL-10 expression with histopathologic type in NPC patients.

Conflict of Interest: There is no conflict of interest.

Source of Funding: This study is self-funded.

Ethical Clearance: The research was conducted after it was approved by the Research Ethics Committee 
of Dr. Soetomo Teaching Hospital Surabaya (181/ Panke.KKE/III/2017).

\section{References}

1. Fibrian KC. Hubungan Antara Klasifikasi Histopatologis dengan Respon Kemoradiasi Berdasarkan Gambaran CT Scan pada Penderita Karsinoma Nasofaring. Faculty of Medicine; 2010.

2. Budiani DR, Hutahaean S, Haryana SM, Soesatyo $\mathrm{MH}$, Sosroseno W. Interleukin-10 levels in EpsteinBarr virus-associated nasopharyngeal carcinoma. $\mathrm{J}$ Microbiol Immunol Infect Wei mian yu gan ran za zhi. 2002;35(4):265-8.

3. Mulyati DE. Perbedaan Ekspresi Interleukin-10 (Il-10) Pada Karsinoma Nasofaring Who Tipe 3 Stadium Iii Dan Stadium Iv. Universitas Sebelas Maret; 2015.

4. Wang M, Zou H, Zhang W, Hou K. Emotional Intelligence and Subjective Well-Being in Chinese University Students: The Role of Humor Styles. J Happiness Stud [Internet]. 2019;20(4):1163-78. Available from: https://doi.org/10.1007/s10902018-9982-2

5. Anugrahini HN, Nuswantoro D, Sriyono. Progressive muscle relaxation and symptoms of women with breast cancer undergoing adjuvan chemotherapy. Indian J Forensic Med Toxicol [Internet]. 2019;13(4):1605-10. Available from: https://www.scopus.com/inward/record. uri?eid $=2$-s2.0-85075939962 \& doi $=10.5958 \%$ 2F0973-9130.2019.00535.8 \& partnerID $=40 \& \mathrm{md}$ $5=$ fbc5483d37571dde0c9bcf3160d046e 8

6. Rasad S, Kartoleksono S, Ekayuda I. Radiologi diagnostik. Edisi. 2005;2:85-6.

7. Ren JS, Freedman ND, Kamangar F, Dawsey SM, Hollenbeck AR, Schatzkin A, et al. Antioxidant and in vivo anti-hyperglycemic activity of Muntingia calabura leaves extracts. Appetite. 2014; 4(3):654-61.

8. Mocellin S, Marincola FM, Young HA. Interleukin-10 and the immune response against cancer: a counterpoint. J Leukoc Biol. 2005;78(5):1043-51.

9. Lavaee F, Ghapanchi J, Anjomruz A, Malekzadeh $M$. The evaluation of the serum level of IL-10 in OLP patients. Comp Clin Path. 2018;27(1):131-4.

10. Poh YW, Gan SY, Tan EL. Effects of IL-6, IL10 and TGF- $\beta$ on the expression of survivin and apoptosis in nasopharyngeal carcinoma TW01 cells. Exp Oncol. 2012;

11. Iwakiri D. Epstein-Barr virus-encoded RNAs: key molecules in viral pathogenesis. Cancers (Basel). 2014;6(3):1615-30.

12. Ferawati L, Hasih Sri Lamdari, Dimas Teguh Saputra JS. Bercerita, Berpuisi, dan bernyanyi dalam Pembelajaran Bahsa Indonesia di Sekolah Dasar untuk Meningkatkan Kognitif Anak. Pendidik Guru Sekol Dasar FKIP UNS. 2012;

13. Lu JJ, Cooper JS, Lee AWM. Nasopharyngeal cancer: multidisciplinary management. Springer Science \& Business Media; 2010.

14. Thompson LDR. Update on nasopharyngeal carcinoma. Head Neck Pathol. 2007;1(1):81-6.

15. George B, Minello C, Allano G, Maindet C, Burnod A, Lemaire A. Opioids in cancer-related pain: current situation and outlook. Support Care Cancer. 2019;27(8):3105-18.

16. Widjaja AE, Chen JV, Sukoco BM, Ha QA. Understanding users' willingness to put their personal information on the personal cloud-based storage applications: An empirical study. Comput Human Behav. 2019;91:167-85.

17. Amini MH, Azar FM, Wilson BR, Smith RA, Mauck BM, Throckmorton TW. Comparison of outcomes and costs of tension-band and lockingplate osteosynthesis in transverse olecranon fractures: a matched-cohort study. Am J Orthop (Belle Mead NJ). 2015;44(7):E211-5.

18. Terzic TT, Boricic MI, Pendjer IP, Zecevic DTR, Tomanovic NR, Brasanac DC, et al. Prognostic significance of clinical parameters and Epstein-Barr virus infection in non-endemic undifferentiated carcinoma of nasopharyngeal type: a Serbian report. Med Oncol. 2011;28(4):1325-30.

19. Fujieda S, Lee K, Sunaga $H$, Tsuzuki H, Ikawa H, Fan $\mathrm{G}$, et al. Staining of interleukin-10 predicts clinical outcome in patients with nasopharyngeal carcinoma. Cancer Interdiscip Int J Am Cancer Soc. 1999;85(7):1439-45.

20. Tan E, Selvaratnam G, Kananathan R, Sam C. Quantification of Epstein-Barr virus DNA load, interleukin-6, interleukin-10, transforming growth factor- $\beta 1$ and stem cell factor in plasma of patients with nasopharyngeal carcinoma. BMC Cancer. 2006;6(1):227. 